\title{
OPTIMALISASI LAMA PEMAPARAN LASERPUNKTUR PADA TITIK REPRODUKSI TERHADAP PENINGKATAN NILAI HEPATO SOMATIC INDEX (HSI) DAN GONADO SOMATIC INDEX (GSI) IKAN GABUS (Channa striata)
}

\author{
Pungky Slamet WK \\ Biology Department of Mathematics and Natural Sciences Faculty \\ PGRI Adi Buana University Surabaya \\ Email : slametswk@yahoo.com
}

\begin{abstract}
ABTRACT
Snakefish fishing continuously can reduce the number of mature stem gonad great sizenya increasingly few in number in nature will certainly affect the reduction in seed production in the waters and may even become extinct. Efforts should be made restoking with laserpuncture technology. Laserpuncture technology has been shown to accelerate the maturation of the gonads in tilapia, catfish, shrimp, crab, but has never been tried on the snakefish brood (Channa striata). The purpose of this study to obtain optimum exposure time laserpuncture at the acupoint of reproduction to increase the value of HSI and GSI snakefish (Channa striata) male parent in order to get ready for spawning. Research experiments using CRD with 5 treatments and repeated 3 times. To get the value of HSI and GSI by weighing the weight, liver weight and gonadnya. The sample used in this study snakefish brood 1 year old male with a weight range from 1100-1400 grams have never spawn. HSI and GSI value analysis using ANOVA Gen Stat program version 15. The results showed exposure at the acupoint of reproduction laserpuncture significant effect $(\mathrm{P}<0.05)$ increase in the value of HSI and GSI. Laserpuncture exposure time at the acupoint of reproduction for 4 seconds proved to be optimal to increase the value of HSI and GSI parent catfish than in controls.
\end{abstract}

Keywords: Laserpuncture, the value of HSI and GSI snakefish

\section{PENDAHULUAN}

Ikan gabus merupakan salah satu jenis ikan karnivora yang suka memakan hewan lain yang lebih kecil, seperti cacing, udang, ketam, plankton dan udang renik (Djuhanda, 1981). Jenis ikan ini secara alami banyak ditemukan di sungai dan bendungan serta belum pernah dibudidayakan. Nilai ekonomi ikan gabus ini terus meningkat seiring dengan kemanfaatanya dalam bentuk ikan segar juga telah digunakan sebagai bahan pembuatan kerupuk dan olahan lainnya. Pada ukuran benih dimanfaatkan sebagai pakan ikan hias dan pada ukuran konsumsi ikan ini sangat digemari karena memiliki tekstur daging yang tebal dan putih dengan rasa yang khas serta tidak mempunyai duri selip (Makmur, 2003).

Nilai gizi ikan gabus cukup tinggi, karena mengandung protein sebesar $42 \%$, lemak $1,7 \%$, dan berbagai mineral dan vitamin A. Dari $42 \%$ protein $6,2 \%$ berupa albumin. Jumlah albumin pada ikan gabus ini sangat tinggi dibanding sumber protein hewan lainnya. Albumin merupakan jenis protein terbanyak di dalam plasma yang mencapai kadar $60 \%$ dan bersinergi dengan mineral $\mathrm{Zn}$ yang sangat dibutuhkan untuk perkembangan sel maupun pembentukan jaringan sel baru seperti penyembuhan luka akibat operasi dengan demikian ikan gabus sangat potensial untuk dikembangkan dalam industri pangan. Selain itu, kadar lemak ikan gabus relative rendah dibandingkan kadar lemak jenis-jenis ikan lainnya seperti ikan tongkol $24,4 \%$ dan ikan lele $11,2 \%$ lemak memungkinkan umur simpan ikan gabus lebih panjang karena kemungkinan mengalami ketengikan lebih lama.

Banyaknya manfaat ikan gabus yang dikonsumsi maupun digunakan untuk obat pada berbagai jenis penyakit. Hal mendorong masyarakat melakukan penangkapan ikan gabus di alam secara terus-menerus. Tentunya penangkapan ikan gabus yang semakin meningkat ini dapat menyebabkan populasi ikan gabus yang terdapat di perairan semakin menurun sehingga pertumbuhan ikan gabus kurang optimal. Kurang optimalnya pertumbuhan ini banyak disebabkan ikan yang berukuran kecil sudah dapat ditangkap. Musim penangkapan ikan gabus di alam banyak dilakukan pada musim kemarau dan sebagian besar ikan gabus yang tertangkap $75-80 \%$ berada pada kondisi matang gonad (Bijaksana, 2006). Apabila penangkapan dilakukan secara terus menerus maka ikan gabus yang tertangkap akan semakin besar sizenya atau bahkan mungkin induk ikan gabus matang gonad yang tertangkap semakin banyak akaibatnya induk matang gonad di perairan berkurang jumlahnya. Jika ditinjau dari beberapa lokasi, pemijahan alami ikan 
gabus terjadi di awal musim penghujan sampai pertengahan musim penghujan. Induk ikan gabus dapat memijah pertama kali pada umur sekitar 9 bulan pada ukuran panjang sekitar $21 \mathrm{~cm}$ (Haniffa et al.1996). Di Waduk Kedongombo Jawa Tengah, ikan gabus betina mulai matang gonad pada ukuran panjang total $18,5 \mathrm{~cm}$ (Kartamihardja,1994). Permasalahannya di lapangan pemijahan ikan gabus bersifat musiman.

Hal inilah salah satu penyebab menurunnya populasi ikan gabus di alam banyak selain itu juga disebabkan semakin besarnya ukuran ikan gabus yang tertangkap saat ini, sehingga diperlukan budidaya ikan ini perlu dikembangkan karena cara budidaya ikan gabus sebetulnya tidak susah cukup dengan pemijahan alami selama musim hujan (Bloch,1793). Secara alami, faktor fisiologis dan lingkungan dijadikan pertimbangan sebagai isyarat penting dalam merangsang pemijahan pada ikan gabus ini. Pada wilayah tropis, perubahan temperatur perairan dan amplitude ketinggian permukaan air disebabkan oleh pergantian musim dapat menjadi trigger untuk ikan melakukan pemijahan (Zairin et al. 2001).

Untuk mengatasinya populasi ikan gabus yang semakin lama populasinya berkurang dialam maka perlu dilakukan restoking secara insitu dengan mengunakan teknologi laserpunktur guna mendapatkan induk ikan gabus siap untuk dipijahkan secara massal. Setelah kita peroleh induk ikan gabus matang gonad dan siap dipijahkan, anakan yang diperoleh dibesarkan sampai ukuran tertentu selanjutnya ditebarkan lagi ke alam untuk menambah jumlah populasinya. Pelepasan anakan di alam dilakukan pada daerah yang bukan sentra penangkapan ikan, sehingga ikan yang ditebar tidak terganggu atau tertangkap baik secara kebetulan maupun sengaja. Teknologi yang digunakan dalam restoking ini adalah paparan laserpunktur pada titik reproduksi guna mempercepat peningkatan nilai HSI dan GSI ikan gabus (Channa striata) jantan. Peningkatan nilai HSI dan GSI sebagai salah satu indikator bahwa ikan gabus matang gonad dan induk siap untuk dipijahkan. Hasil penelitian yang dilakukan pada ikan lele menunjukkan bahwa paparan laserpunktur pada titik reproduksi dapat meningkatkan nilai GSI dan mempercepat pematangan gonad, memperpendek siklus reproduksi dan merangsang pemijahan dan pengadaan benih serta pada ikan lele (Kusuma et al., 2007; Hariani dan Kusuma, 2008, 2009, 2010). Diharapkan dari hasil penelitian pada ikan lele ini dapat diaplikasikan pada ikan gabus dengan tujuan untuk mendapatkan waktu optimal pemaparan laserpunktur pada titik reproduksi terhadap peningkatan nilai HSI dan GSI ikan gabus (Channa striata) jantan guna mendapatkan induk matang gonad dan siap untuk dipijahkan dalam sekala massal, kontinu agar segera tercapai dan benih yang diperoleh banyak selanjutnya ditebar guna untuk mempertahankan populasi yang semakin lama berkurang dialam.

\section{MATERI DAN METODE}

Penelitian ini dilakukan di Unit Pengelola Budidaya Air Tawar (UPBAT) Kepanjen, Malang. Penelitian eksperimen menggunakan Rancangan Acak Lengkap (RAL) dengan 5 perlakuan dan diulang 3 kali. Paparan laserpunktur dilakukan seminggu sekali selama 8 minggu. Untuk mengetahui kecepatan pematangan gonad diukur dari peningkatan nilai HSI dan GSI. Sampel dalam penelitian ini induk ikan gabus jantan umur 1 tahun sebanyak 32 ekor dengan kisaran berat antara 107190 gram hasil tangkapan di perairan Sidoarjo. Ikan gabus setelah ditangkap perlu diaklimatisasi sebelum mendapat perlakuan. Induk ikan gabus ditempatkan pada kolam terpal berukuran $90 \mathrm{~cm}$ x $2 \mathrm{~m}$ x $2 \mathrm{~m}$ yang telah diberi aerasi. Ikan dipuasakan selama 2 hari, hal ini dimaksudkan untuk memperkenalkan pakan komersial setelah ikan mengalami transportasi. Dosis pakan formula dengan kandungan protein $36 \%$ buatan prabrik Pokphan 781-3 produksi CP Prima diberikan sebanyak $4 \%$ dari bobot badannya setiap hari. Pakan diberikan pagi dan sore hari. Frekuensi pemberian pakan diberikan dua kali sehari yaitu pukul 10.00 WIB dan pukul 16.00 WIB. Proses aklimatisasi induk ikan gabus selama dua minggu. Setelah aklimatisasi. Induk ikan gabus dipapar laserpunktur pada titik reproduksi tepatnya di $2 / 3$ bagian ventral tubuh selama $0,2,4,6,8$ detik/minggu selama 8 minggu dan sebagai pembanding kelompok tanpa dipapar laserpunktur. Laserpunktur yang digunakan sebagai biostimulasi dalam penelitian ini adalah jenis soft laser $\mathrm{He}-\mathrm{Ne}$ yang memiliki panjang gelombang $632,8 \mathrm{~nm}$, luas keluaran cahaya $0,2 \mathrm{~cm}^{2}$ dan daya keluaran sinar laser $5 \mathrm{~mW} / \mathrm{cm}^{2}$ equivalen dengan $0,375 \mathrm{Joul} / \mathrm{cm}^{2}$. Laser ini memiliki panjang gelombang dengan kisaran aman untuk dipakai sebagai biostimulasi organ biologi (Karu, 2000). Setelah 8 minggu induk ikan gabus jantan ditimbang untuk mendapatkan berat badan dan dibiopsi untuk mendapatkan berat hepar dan gonadnya. Hasil penimbangan berat badan, berat hepar dan berat gonad diperlukan untuk menentukan nilai Hepato Somatic Index (HSI) dan nilai Gonado Somatic Index (GSI). Untuk menentukan nilai Hepato Somatic Index (HSI).

$$
\begin{aligned}
& \text { HSI } \%=\frac{W h}{W t-W h} \times 100 \\
& \text { HSI : Hepato Somatic Index } \\
& \text { Wh : Weight hepar }(\mathrm{g}) \\
& \text { Wt : Weight body }(\mathrm{g})
\end{aligned}
$$

(Effendie. 2002). 
Selanjutnya untuk menentukan nilai Gonado Somatic Index (GSI).

GSI $\%=\frac{W g}{W t-W g} \times 100$

GSI : Gonado Somatic Index

$\mathrm{Wg}$ : Weight gonad $(\mathrm{g})$

$\mathrm{Wt}$ : Weight body (g)

(Effendie. 2002).

\section{ANALISIS DATA}

Untuk mengetahui pengaruh induksi laserpunktur pada titik reproduksi ikan gabus terhadap nilai Hepato Somatic Indeks (HSI) dan nilai Gonado Somatic Indeks (GSI). Hasil pengukuran peningkatan nilai HSI dan GSI selanjutnya dianalisis dengan menggunakan ANOVA satu arah program Gen Stat versi 15, untuk melihat pengaruh antar perlakuan dan kontrol. Apabila F hitung > F tabel dengan signifikansi 5\% maka dilakukan uji lanjut dengan uji Duncan dengan taraf signifikan 5\% sehingga dapat diketahui lebih jelas pengaruh antar perlakuannya.

\section{HASIL DAN PEMBAHASAN}

Rata-rata hasil paparan laserpunktur pada titik reproduksi berpengaruh signifikan $(\mathrm{P}<0.05)$ terhadap peningkatan nilai HSI induk ikan gabus jantan dibandingkan dengan kelompok kontrol (Tabel 1).

Tabel 1. Nilai rerata dan simpangan baku HSI induk ikan gabus jantan antara kelompok yang diinduksi laserpunktur dan kontrol.

\begin{tabular}{|l|l|l|l|}
\hline Kelompok & $\begin{array}{l}\text { Lama } \\
\text { pemaparan }\end{array}$ & $\mathrm{N}$ & $\begin{array}{l}\text { HSI } \\
\text { Rerata } \pm \text { Standar } \\
\text { Deviasi }\end{array}$ \\
\hline Kontrol & 0 detik & 3 & $0.25 \pm 0,03^{\mathrm{b}}$ \\
\hline Laserpuktur & 2 detik & 3 & $0,29 \pm 0,04^{\mathrm{b}}$ \\
\cline { 2 - 4 } & 4 detik & 3 & $0,58 \pm 0,02^{\mathrm{a}}$ \\
\cline { 2 - 4 } & 6 detik & 3 & $0,31 \pm 0,04^{\mathrm{b}}$ \\
\cline { 2 - 4 } & 8 detik & 3 & $0,26 \pm 0,02^{\mathrm{b}}$ \\
\hline
\end{tabular}

Catatan: Nilai pada kolom diikuti oleh superskrip berbeda menunjukkan berbeda signifikan $(\mathrm{P}<0,05)$.

Lama perlakuan paparan laserpunktur 4 detik optimal untuk peningkatan nilai HSI induk ikan gabus jantan.

Rata-rata nilai GSI induk ikan gabus jantan meningkat signifikan $(\mathrm{P}<0.05)$ setelah dipapar laserpunktur pada titik reproduksi jika dibandingkan dengan kelompok kontrol. Lama paparan laserpunktur 4 detik terbukti optimal untuk meningkatkan nilai GSI induk ikan gabus jantan (Tabel 2).

Tabel 2. Nilai rerata dan simpangan baku GSI induk ikan gabus jantan antara kelompok yang diinduksi laserpunktur dan kontrol.

\begin{tabular}{|l|l|l|l|}
\hline Kelompok & $\begin{array}{l}\text { Lama } \\
\text { pemaparan }\end{array}$ & N & $\begin{array}{l}\text { GSI } \\
\text { Rerata } \pm \text { Standar } \\
\text { Deviasi }\end{array}$ \\
\hline Kontrol & 0 detik & 3 & $0.27 \pm 0.11^{\mathrm{c}}$ \\
\hline Laserpuktur & 2 detik & 3 & $0.42 \pm 0.03^{\mathrm{b}}$ \\
\cline { 2 - 4 } & 4 detik & 3 & $0.65 \pm 0.08^{\mathrm{a}}$ \\
\cline { 2 - 4 } & 6 detik & 3 & $0.42 \pm 0.04^{\mathrm{b}}$ \\
\cline { 2 - 4 } & 8 detik & 3 & $0.37 \pm 0.05^{\mathrm{bc}}$ \\
\hline
\end{tabular}

Catatan: Nilai pada kolom diikuti oleh superskrip berbeda menunjukkan berbeda signifikan $(\mathrm{P}<0,05)$

Hasil penelitian ini menunjukkan bahwa pemaparan laserpunktur pada titik reproduksi induk ikan gabus dapat meningkatkan aktifitas fisiologi dalam tubuhnya. Hal ini ditunjukkan bahwa lama pemaparan laserpunktur 4 detik pada titik reproduksi terbukti optimalisasi untuk meningkatkan nilai HSI dan GSI induk ikan gabus jantan. Nilai HSI induk ikan gabus jantan dicapai tertinggi sebesar $0,58 \%$ dan terendah $0,25 \%$ dan diikuti dengan peningkatan nilai GSI induk ikan gabus jantan dicapai tertinggi sebesar $0,65 \%$ pada TKG V dan terendah $0,27 \%$ pada TKG I. Menurut Effendi (1997), sejalan dengan peningkatan berat gonad akibat peningkatan pelepasan hormon gonadotropin, maka gonad akan merespon dengan semakin bertambah berat gonadnya sampai batas maksimum ketika terjadi 
pemijahan. Namun peningkatan nilai GSI induk ikan gabus jantan lebih kecil jika dibandingkan dengan nilai GSI induk ikan gabus betina. Menurut Makmur (2003), nilai rataan GSI ikan betina lebih besar dari nilai rataan GSI ikan jantan pada tingkat kematangan gonad yang sama. Hal ini disebabkan perningkatan berat ovarium selalu lebih besar dari pada peningkatan berat testis induk ikan gabus. Nilai GSI yang diperoleh pada peneitian ini yaitu $0,65 \%$, hal ini mengindikasikan bahwa induk ikan gabus merupakan kelompok ikan yang mempunyai nilai GSI kecil dan dikategorikan sebagai ikan yang dapat memijah lebih dari satu kali setiap tahunnya. Hal ini sesuai dengan Bagenal (1978), menyatakan bahwa ikan yang mempunyai nilai $\mathrm{TKG}<20 \%$ adalah kelompok ikan yang dapat memijah lebih dari satu kali tiap tahunnya. Hal ini juga sesuai dengan hasil penelitian Bagenal (1978) dalam Wahyu (2010), yang menyatakan bahwa ikan yang mempunyai nilai GSI lebih kecil dari 20\% adalah kelompok ikan yang dapat memijah lebih dari satu kali setiap tahunnya. Nilai GSI merupakan salah satu indikator perkembangan dan kematangan gonad induk ikan gabus.

Peningkatan nilai HSI dan GSI akibat paparan pada titik reproduksi ini dapat terjadi karena paparan laserpunktur yang di induksikan pada titik reproduksi ini berupa energi gelombang elektromagnetik, selanjutnya jika energi gelombang elektromagnetik ini dipaparkan pada titik reproduksi energi gelombang elektromagnetik akan menembus demis sampai epidermis yang kaya akan ujungujung syaraf perifir, selanjutnya energi gelombang elektromagnetik ini jika tepat mengenai ujung syaraf perifir ini energi gelombang elektromagnetik akan diubah menjadi sinyal listrik didalam membran sel syaraf. Sinyal listrik akan menyebabkan depolarisasi membran sel syaraf (Kusuma dkk., 2013). Akibat depolarisasi, membran sel syaraf akan mengalami potensial aksi dan membran sel syaraf akan merespon dengan terbukanya saluran $\mathrm{Ca}^{2+}$ ektraseluler. $\mathrm{Ca}^{2+}$ ektraseluler akan masuk melalui calcium sensing receptor (CaSR) atau melalui Voltage Gated Calcium Channels (VGCC) (Berridge dkk., 2000; Clapham, 2007). Akibat masuknya $\mathrm{Ca}^{2+}$ ektraseluler ke dalam intraseluler ini, $\mathrm{Ca}^{2+}$ intraseluler akan meningkat dan peningkatan aktivitas $\mathrm{Ca}^{2+}$ dilacak dengan calsineurin, selanjutnya $\mathrm{Ca}^{2+}$ intraseluler akan merangsang gelembung sinaptik untuk melepaskan neurotransmitter secara eksositosis ke dalam celah sinap. Di celah sinap neurotransmitter akan berikatan dengan reseptor spesifik di postsinap, akibatnya pada membran sel postsinap dapat eksitatori atau inhibitori.

Jika ikatan reseptor dengan neurotransmiter di postsinap eksitatori, maka impuls akan dilanjutkan sampai akhirnya menuju otak. Di jaringan otak akan terjadi serangkaian reaksi fisiologi ditandai dengan aktifnya enzim Glutamic Acid
Decarboxylase-65 (GAD-65), enzim ini akan merangsang neuron GABAergik untuk mensintesis Gama Amino Butiric Acid (GABA) di jaringan otak. GABA akan merangsang neuron hipotalamus dan neuron hipofisis (Kusuma dkk., 2012c). Ditegaskan oleh (Kah, O. \& Dufour, S., 2011; Kusuma dkk., (2012b) bahwa GABA akan merangsang neuron hipotalamus untuk melepaskan hormon gonadotropin (GnRH). GnRH akan merangsang neuron hipofisis untuk melepaskan hormon gonadotropin (GtH-I dan GtH-II). Selanjutnya GtHI dan GtH-II dilepaskan secara sistemik, sehingga kadar GtH-I dan GtH-II dalam serum darah meningkat.

Ditegaskan oleh Kusuma dkk., (2012b) bahwa GABA merangsang neuron hypothalamus untuk melepaskan hormon gonadotropin (GnRH). GnRH selanjutnya akan merangsang neuron hipofisis untuk melepaskan hormon gonadotropin (GtH-I dan GtHII). Selanjutnya GtH-I dan GtH-II dilepaskan secara sistemik, sehingga kadar GtH-I dan GtH-II dalam serum darah meningkat. GtH-I dan GtH-II berperan merangsang gonad untuk menghasilkan hormon steroid yaitu testosteron dan $17 \beta$-estradiol yang akan berpengaruh pada spermatogenesis. GtH-I berfungsi untuk merangsang perkembangan dan proliferasi sel sertoli untuk menghasilkan ABP (Androgen Binding Protein) yang akan memacu spermatogonium untuk memulai proses spermatogenesis. GtH-II berfungsi merangsang sel intersitial atau sel Leydig untuk mensekresikan hormon testosteron (androgen). ICSH (Intertitial Cell Stimulating Hormone) berfungsi mempengaruhi dan merangsang perkembangan tubulus seminiferus dan sel Sertoli untuk menghasilkan ABP (Androgen Binding Protein) yang memacu pembentukan sperma. Testosteron dan Androgen Binding Protein (ABP) secara bersama-sama mengendalikan pembentukan sperma dalam proses spermatogenesis dan menstimulasi perkembangan spermatogenik. Hal ini mengindikasikan bahwa paparan laserpunktur pada titik reproduksi dapat meningkatkan kinerja hormon yang merupakan sistem kontrol reproduksi untuk mempercepat pertumbuhan, perkembangan dan pematangan gonad ikan gabus. Selain itu hasil penelitian pada ikan gabus ini dapat membuktikan bahwa ikan gabus sebagai salah satu jenis ikan karnivora di perairan rawa terbukti dapat dipelihara dan dikembangbiakan atau dikembalikan ke lingkungan untuk mempertahankan populasi yang semakin lama berkurang di alam. Namun apabila intensitas penangkapan di perairan terus dilakukan dan tidak dibatasi frekuensinya maka akan mengarah pada recruitment overfishing, yaitu penangkapan pada ikan-ikan yang telah matang gonad sehingga ikan-ikan tersebut tidak memiliki kesempatan untuk bereproduksi, akibatnya populasi ikan gabus di perairan semakin lama semakin berkurang di alam. (Saputra et al., 2009). 


\section{KESIMPULAN}

Pemaparan laserpunktur pada titik reproduksi terbukti dapat meningkatkan nilai HSI dan GSI induk ikan gabus jantan.

Pemaparan laserpunktur selama 4 detik pada titik reproduksi optimal untuk meningkatkan nilai HSI dan GSI induk ikan gabus jantan.

Ikan gabus dapat dikembangbiakan atau dikembalikan ke lingkungan rawa guna mempertahankan populasi yang semakin lama berkurang di alam.

\section{DAFTAR PUSTAKA}

Berridge, M. J., P. Lipp and M. D.Bootman.2000. The versatility and universality of calcium signalling. Nat. Rev. Mol. Cell Biol. 1: 11-21.

Bijaksana U. 2006. Studi pendahuluan bio-eko reproduksi snakehead di rawa Bangkau Propinsi Kalimantan Selatan. Simposium Nasional Bioteknologi dalam Akuakultur 2006. Departemen Budidaya Perairan Fakultas Perikanan dan Ilmu Kelautan Institut Pertanian Bogor dan Balai Riset Perikanan Budidaya Air Tawar Badan Riset Kelautan dan Perikanan. 5 Juli 2006.

Bijaksana U. 2011b. The effect of some feed types to development of snakehead gonad, Channa striata in concrete tank. Chlorophyl. Jurnal Ilmiah lmu-Ilmu Pertanian. ISSN1858-3954. Vol, 8, No 1, 1 Pebruari 2012. Hal 441-448.

Clapham, D. E. 2007. Calcium signaling. Cell 131: 1047-1058

Djuhanda, T. 1981. Dunia Ikan. Armico. Bandung.

Effendi, M.I. 2002. Biologi Perikanan. Yogyakarta: Yayasan Pustaka Nusatama.

Effendie, M.I. 1997. Biologi Perikanan. Yayasan Dewi Sri. Bogor.

Haniffa MA, Shaik MS, Rose TM. 1996. Induction of ovulation in Channa striatus (Bloch) by sGnRHa. Fishing Chimes. 16: 23-24.

Kah, O. and S. Dufour. 2011. Conserved and divergent features of reproductive neuroendocrinology in teleost fishes. Hormones and Reproduction of Vertebrates. Academic Press. 2 : 15-42.

Kartamihardja ES. 1994. Biologi reproduksi populasi ikan gabus, Channa striata di waduk Kedungombo. Bogor: Buletin Perikanan Darat 12 (2): 113-119.

Kusuma P.S.W. 2013. Mekanisme pelepasan hormone gonadotropin ikan lele (Clarias sp) setelah dipapar laserpunktur pada titik reproduksi. Disertasi. Pascasarjana Fakultas Perikanan dan Ilmu Kelautan. Universitas Brawijaya, Malang

Kusuma P.S.W., Marhendra A.P.M., Aulanni'am. dan Marsoedi. 2012b. Calcineurin expression against the protein kinase $\mathrm{C}$ in catfish (Clarias sp.) skin tissue following laserpuncture exposures at reproduction acupoints. International Journal of Engineering \& Technology IJET-IJENS Vol:12 No:05. 97-10. (C) October 2012 IJENS.

Kusuma P.S.W., Marhendra A.P.M., Aulanni'am. dan Marsoedi. 2012c.Mekanisme Pelepasan Hormon Gonadotropin (GtH-II) Ikan Lele (Clarias sp) Setelah Di Induksi Laserpunktur Pada Titik Reproduksi. Journal Sains Dan Teknologi Indonesia.Vol :12 No: 3 : 2092016.

Kusuma, P. S. W ., D. Hariani., A. T. Mukti. dan W. A. Satyantini. 2007. Aplikasi teknologi laser untuk peningkatan produksi lele dalam rangka pengembangan ekonomi masyarakat ekonomi masyarakat desa di Kabupaten Boyolali Jawa Tengah. Laporan Penelitian. LP3K Kabupaten Boyolali, Boyolali.

Makmur, S. 2003. Biologi Reproduksi, Makanan dan Pertumbuhan Ikan Gabus (Channa striata Bloch) di Daerah Banjiran Sungai Musi Sumatera Selatan. [Tesis] Program Pasca Sarjana, IPB, Bogor.

Rohmawati, S. 2010. Kandungan Albumin Ikan Gabus (Ophiocephalus striatus) Berdasarkan Berat Badan Ikan. Skripsi. Universitas Negeri Malang. Malang.

Saputra, S. W., P. Soedarsono dan G. A. Sulistyawati. 2009. Beberapa Aspek Biologi Ikan Kuniran (Upeneus spp) di Perairan Demak. Jurnal Saintek Perikanan. UNDIP. Semarang, 5 (1): 1-6.

Sudarminto dan Yuwono, 2002. Analisis Karakteristik Fisik Bahan Pangan. Jurusan THP Fakultas Teknologi Pertanian Univ. Brawijaya. Malang.

Zairin MJr, Furukawa K, Aida K. 2001.Induction of spawning in the tropical walking catfish, Clariabatrachus by controlling water level and temperature. Biotropia 16:18-27. 